\title{
Species-specific structural and functional diversity of bacterial communities in lichen symbioses
}

\author{
Martin Grube ${ }^{1}$, Massimiliano Cardinale ${ }^{2}$, João Vieira de Castro $\mathrm{Jr}^{2}$, Henry Müller ${ }^{2}$ \\ and Gabriele Berg ${ }^{2}$ \\ ${ }^{1}$ Institute of Plant Sciences, Karl-Franzens-University of Graz, Graz, Austria and \\ ${ }^{2}$ Institute of Environmental Biotechnology, Graz University of Technology, Graz, Austria
}

\begin{abstract}
Lichens are generally considered as mutualisms between fungi and green algae or cyanobacteria. These partnerships allow light-exposed and long-living joint structures. The unique organization of lichens provides still unexplored environments for microbial communities. To study lichenassociated bacterial communities, we analyze samples, by a polyphasic approach, from three lichen species (Cladonia arbuscula, Lecanora polytropa and Umbilicaria cylindrica) from alpine environments. Our results indicate that bacteria can form highly structured, biofilm-like assemblages on fungal surfaces and reach considerable abundances of up to $10^{8}$ cells per gram fresh weight. Fluorescence in situ hybridization reveals the predominance of Alphaproteobacteria. Microbial fingerprints performed by PCR-single-strand conformation polymorphism analysis using universal and group-specific primers show distinct patterns for each lichen species. Characterization of cultivable strains and presence of functional genes in the total fraction suggest the involvement of associated bacteria in nutrient cycling. Ubiquitous nifH genes, which encode the nitrogenase reductase, show a high diversity and are assigned to Alphaproteobacteria and Firmicutes, for example, Paenibacillus. Cultivable strains mainly belonging to the genera Acinetobacter, Bacillus, Burkholderia, Methylobacterium and Paenibacillus show lytic (chitinolytic, glucanolytic, and proteolytic) activities, hormone production (indole-3-acetic acid) as well as phosphate mobilization and antagonistic activity toward other microorganisms. The traditional concept of lichens has to be expanded to consider multiple bacterial partners.
\end{abstract}

The ISME Journal (2009) 3, 1105-1115; doi:10.1038/ismej.2009.63; published online 25 June 2009

Subject Category: microbial ecology and functional diversity of natural habitats

Keywords: lichen symbiosis; FISH; SSCP; bacteria; nitrogen fixation

\section{Introduction}

Fossil and molecular phylogenetic evidence show that the lichen lifestyle was established at least 600 million years ago (Yuan et al., 2005) and that it is basal in filamentous ascomycete fungi (Lutzoni et al., 2001). Lichens are ecologically diverse and many, often pioneering species, can grow with exceptionally low supply of nutrients. Many lichen symbioses tolerate extreme environmental conditions that are unfavorable for long-term survival of individual partners. Even under rather hostile circumstances, the composite organisms or thalli can live up to thousand years (Denton and Karlén, 1973; Grube and Hawksworth, 2007). Lichens are traditionally considered as symbioses between a

Correspondence: G Berg, Institute of Environmental Biotechnology, Graz University of Technology, Graz, Austria.

E-mail: gabriele.berg@TUGraz.at

Received 9 February 2009; revised 15 April 2009; accepted 21

April 2009; published online 25 June 2009 fungal species and one or more algae or cyanobacteria; yet, there is a considerable range of further associations and numbers of partners (Hawksworth, 1988). The diversity of co-inhabiting fungi is better known because of morphologically distinct structures: more than a thousand fungal species grow specifically on lichens, ranging from commensals to pathogens (Lawrey and Diederich, 2003). However, abundance and diversity of the externally inconspicuous bacterial communities are still poorly understood.

Lichen-associated bacteria were found only by previous studies applying cultivation-dependent approaches: the detected strains were assigned to Azotobacter, Bacillus, Beijerinckia, Clostridium, and Pseudomonas (Henkel and Yuzhakova, 1936; Iskina, 1938; Scott 1956; Panosyan and Nikogosyan, 1966; Henkel and Plotnikova, 1973). A few recent molecular approaches, still based on cultivation, indicated that the diversity of bacteria might be much higher (Lenova and Blum, 1983; Gonzáles et al., 2005; Cardinale et al., 2006; Liba et al., 2006) and 
suggested that up to millions of bacterial cells could be present per gram of a lichen thallus but abundance and specific location in the symbiotic structures in different species has only recently been established directly in one lichen species. Cardinale et al. (2008) showed that Alphaproteobacteria form a dominant part of a community in a reindeer lichen.

The objective of this work was to analyze and compare the structure and composition of associated bacterial communities of the lichen species Cladonia arbuscula, Lecanora polytropa and Umbilicaria cylindrica by a polyphasic approach, using combined microscopic (fluorescence in situ hybridization (FISH) and confocal laser-scanning microscopy (CLSM)) and molecular techniques (microbial fingerprints by PCR-single-strand conformation polymorphism analysis (SSCP) using different primer systems). The lichens were selected because they represent the predominant growth types evolved by lichens: brush-like, crust-forming and leaf-like, respectively (Figure 1). The studied species further grow on different substrates (rocks and soil). In addition, we studied variation in nifH genes for evaluation of nitrogen-fixing populations in the lichen symbiosis, as well as functions of the culturable bacterial fraction. The ability to fix atmospheric nitrogen by the nitrogenase enzyme complex is restricted to some bacteria and is a key element in symbiotic interactions of a variety of host organisms, including plants and fungi (Kneip et al., 2007).

\section{Material and methods}

Sampling procedure

Specimens of the lichens C. arbuscula, L. polytropa and $U$. cylindrica (Figure 1) were collected from a wind-swept heath above the tree line in November 2006 and in May 2007 (Austria, Styria, Koralpe, Handalm, approximately $1800 \mathrm{~m}$ altitude, $46^{\circ} 50^{\prime} \mathrm{N}$, $15^{\circ} 01^{\prime}$ O). Lichen samples were collected at three locations within an area of $2 \mathrm{Ha}$. At each location, composite samples of five individuals per species were prepared. Using sterile tweezers, fragments of Cladonia and Umbilicaria were transferred into sterile polyethylene bags. Samples of Lecanora were collected together with underlying rock substrate (to avoid disintegration of the lichen) by chiselling using a hammer. The samples were stored in sterile polyethylene bags until processing. Samples were processed within $3 \mathrm{~h}$ after sampling.

\section{FISH, CLSM and image analysis}

Lichen samples were fixed within $3 \mathrm{~h}$ after collection in 3:1 4\% paraformaldehyde/phosphate-buffered saline (PBS) for $12 \mathrm{~h}$ at $4{ }^{\circ} \mathrm{C}$, washed three times in ice-cold PBS and then stored at $-20^{\circ} \mathrm{C}$ in 1:1 PBS/96\% ethanol. Small pieces $(5-10 \mathrm{~mm}$ length) of fixed thalli were cut in $30 \mu \mathrm{m}$ cryosections and placed into $1.5 \mathrm{ml}$ microcentrifuge tubes. FISH was performed as described by Cardinale et al. (2008). An equimolar mixture of Cy3-labeled EUB338, EUB338II and EUB338III probes (Amann et al., 1990) was used for the detection of all bacteria and 6FAM-labeled Bet42a probe for the detection of Burkholderia and other Betaproteobacteria (Daims et al., 1999; Manz et al., 1992). Bet42a probe was used together with an unlabeled competitor probe to avoid unspecific hybridization of closely related bacteria, or together with the Cy5-labeled Gam42a probe (Manz et al., 1992) for detection of Gammaproteobacteria. For detection of Alphaproteobacteria, Actinobacteria and Firmicutes we used respectively Cy5-labeled ALF968 (Loy et al., 2007), Cy5-labeled HGC 236 (Erhart et al., 1997) and an equimolar mixture of fluorescein-isothiocyanatelabeled LGC354A, LGC354B and LGC354C (Meier et al., 1999). Negative controls were performed with a non-sense FISH probe (NONEUB; Wallner et al., 1993). Different non-sense probes labeled with all the fluorochromes used in the experiments were

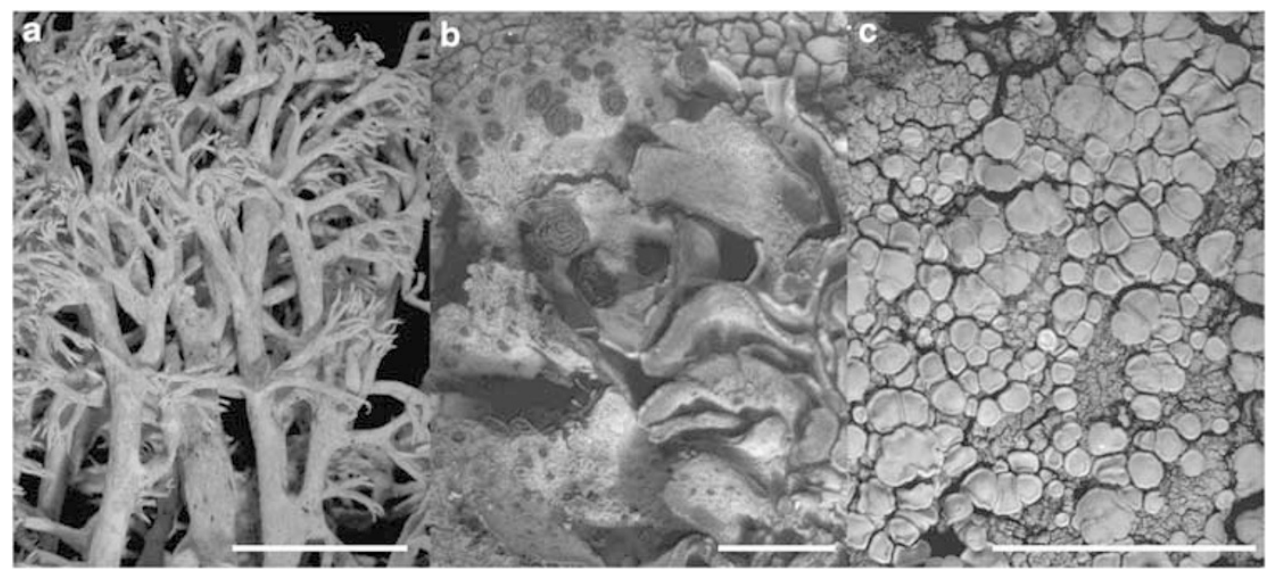

Figure 1 The lichen species studied. (a) The shrub-forming reindeer lichen C. arbuscula on soil. (b) The leaf-like U. cylindrica on rock. (c) The crust-forming $L$. polytropa on rock. Scale bar $=1 \mathrm{~cm}$. 
Table 1 Properties of the probes used for FISH

\begin{tabular}{|c|c|c|c|c|}
\hline Name & Sequence $\left(5^{\prime}-3^{\prime}\right)$ & Target & $\begin{array}{c}\text { Formamide } \\
\text { concentration }(\%)^{\mathrm{a}}\end{array}$ & Reference \\
\hline EUB338 ${ }^{\mathrm{b}}$ & gctgcctcccgtaggagt & Most bacteria & 10 & Amann et al. (1990) \\
\hline EUB338II & gcagccacccgtaggtgt & Planctomycetales & 10 & Daims et al. (1999) \\
\hline EUB338III $^{\mathrm{b}}$ & gctgccacccgtaggtgt & Verrucomicrobiales & 10 & Daims et al. (1999) \\
\hline ALF968 & ggtaaggttctgcgcgtt & Alphaproteobacteria & 40 & Loy et al. (2007) \\
\hline BET42a ${ }^{b}$ & gccttcccacttcgttt & Betaproteobacteria & 40 & Manz et al. (1992) \\
\hline GAM42a ${ }^{\mathrm{b}}$ & gccttcccacatcgttt & Gammaproteobacteria & 40 & Manz et al. (1992) \\
\hline LGC354A ${ }^{\mathrm{b}}$ & tggaagattccctactgc & Firmicutes & 35 & Meier et al. (1999) \\
\hline LGC354B ${ }^{\mathrm{b}}$ & cggaagattccctactgc & Firmicutes & 35 & Meier et al. (1999) \\
\hline LGC354C & ccgaagattccctactgc & Firmicutes & 35 & Meier et al. (1999) \\
\hline HGC236 & aacaagctgataggccgc & Actinobacteria & 20 & Erhart et al. (1997) \\
\hline NONEUB & actcctacgggaggcagc & - & c & Wallner et al. (1993) \\
\hline
\end{tabular}

aThe indicated percentage of formamide are intended for hybridizations at $41^{\circ} \mathrm{C}$.

bused together in equimolar concentration.

${ }^{\mathrm{c}}$ Used as negative control at same formamide concentration as used for positive FISH probe.

applied, as they can show different adhesion properties. All hybridizations were performed at $41^{\circ} \mathrm{C}$ for $1.5-2.5 \mathrm{~h}$. Formamide concentrations and other properties of the FISH probes are described in Table 1. Washing steps with appropriate washing buffer matching the formamide concentration were carried out at $42{ }^{\circ} \mathrm{C}$ for $10 \mathrm{~min}$. Stained samples were immediately dried with compressed air, mounted with ProLong antifadent (Molecular Probes Inc., Eugene, OR, USA) and viewed under a CLSM within $24 \mathrm{~h}$.

Stained lichens were examined using a Leica TCS SP confocal laser-scanning microscope equipped with argon and helium/neon lasers. SYTOX Blue (Ex/Em maximum 444/480 nm) for general visualization of bacteria was excited with the $458 \mathrm{~nm}$ argon laser line. To optimize the resolution of the CLSM, we set the size of the pinhole to $50-60 \%$ of its optimal size to match the Airy disk diameter of the lens used. Sampling of raster points was according to the Nyquist's sampling theorem (for example, $1024 \times 1024$ for a $\times 2$ zoom, $512 \times 512$ for a $\times 4$ zoom). The voltage of the photomultiplier tube was set to $460-560 \mathrm{~V}$. Maximum intensity projections of an appropriate number of optical slices $(0.5-1 \mu \mathrm{m}$ deep) were applied to visualize the lichen sections. Up to 20 scans per optical slice were averaged to improve the image quality and to reduce noise.

Confocal stacks containing signals from three different fluorescent simultaneously were analyzed by z-projection and 3D rendering with the software Imaris 6.0.0 (Bitplane, Zurich, Switzerland). Images containing large amount of unidentifiable autofluorescent objects were discarded. Three-dimensional rendering was carried out by both analyses of extended volumes of the original fluorescent signals and reconstruction of artificial objects (isosurfaces and points).

For every FISH probe staining, 15-30 pictures obtained at least two different thalli and two different FISH experiments per lichen species were used to calculate the number of cells per volume of dry lichen. Every picture is the maximum z-projection of a confocal stack formed by 5-60 confocal planes showing the whole section of an undamaged part of the thallus. The software ImageJ (http:// rsbweb.nih.gov/ij/docs/index.html) implemented with suitable plug-ins was used to count the fluorescent cells and to calculate the lichen volume in every picture.

\section{Molecular fingerprints of lichen-associated bacterial communities}

Fingerprinting of the ecto- and endolichenic bacterial communities by SSCP was carried out as described by Schwieger and Tebbe (1998). Microorganisms of the lichen communities were extracted by mechanical disruption and homogenization of $400 \mu \mathrm{g}$ material in a FastPrep Instrument (BIO101 Systems; Qbiogene, Carlsbad, CA, USA) for $30 \mathrm{~s}$ at speed 5.0. DNA was purified by the GENECLEAN Turbo kit (Qbiogene) containing the special binding buffer guanidine thiocyanate for removal of humic acids. Bacterial 16S rDNA fragments (positions 515927 according to Escherichia coli rDNA sequence numbering) were amplified by PCR with the primers Unibac-II-515f and Unibac-II-927rP (Berg et al., 2005). Alphaproteobacteria were selectively amplified with primers ADF 681F/1492r (5'-AGTGTAGAG GTGAAATT-3 ${ }^{\prime} / 5^{\prime}$-TACGGYTACCTTGTTACGACTT-3') followed by a second PCR with the primers ADF $681 \mathrm{~F} / 927 \mathrm{r}$ (5'-CCCGCTAATTYMTTTGACTT$3^{\prime}$ ) (Blackwood et al., 2005). For specific patterns of Burkholderia, a double-nested PCR was applied using the following primer pair Eub1/Eub2 (5'GAGTTTGATCCTGGCTCAG-3'/ $/ 5^{\prime}$-AGAAAGGAGGT GATCCAGCC-3'), BKH143Fw/BKH1434Rw (5'-TGGG GGATAGCYCGGGG-3 ${ }^{\prime} / 5^{\prime}$-TGCGGTTAGRCTASCYAC $\mathrm{T}-3^{\prime}$ ) and the eubacterial primer pair Unibac-II-515f and Unibac-II-927rP. Pseudomonas was investigated by the primer pairs F311Ps/1459rPs-P (5'-CTGGTC TGAGAGGATGATCAGT-3'/5'-AATCACTCCGTGGTA AACGT-3') and Unibac-II-515f and Unibac-II-927rP 
(Opelt and Berg, 2004), respectively. nifH fragments were obtained with nifH3/19F (5'-ATAGTTAGTTA GCTGCAGCTGCAGTA-3'/5'-GCXATTCTTACTGGXA AAG-3') and nifH11/nifH22 (5'-GACTCCAGCTAA AGGCAGCTGACTC-3' ${ }^{\prime} / 5^{\prime}$-AAGTATGCCATCATCTT CAGCC-3') (Yeager et al., 2004).

The amplicons were separated using the TGGE Maxi System (Biometra, Göttingen, Germany) and visualized by silver staining. Computer-assisted evaluation of bacterial community profiles obtained by SSCP was performed by using the GelCompar program version 4.1 (Applied Maths, Kortrijk, Belgium). Sequence-confirmed bands of plastid origin were excluded from further analysis. The pair-wise similarities of lanes were calculated for each gel by Pearson's correlation. To validate the significance of differences between separated groups, we performed the permutation test according to Kropf et al. (2004).

\section{Bacterial isolation and culturing}

For the isolation of ecto- and endolichenic bacterial communities, 2-4 g of C. arbuscula and U. cylindrica were transferred to a sterile stomacher bag. Extraction of the lichen-associated bacteria was carried out as described by Opelt and Berg (2004). Bacteria from $L$. polytropa were isolated by scraping about $0.2 \mathrm{~g}$ lichen from the rock before suspending in $\mathrm{NaCl}$ solution $(0.85 \%)$ and vortexing for $5 \mathrm{~min}$. For the isolation of the endolichenic bacterial communities of $C$. arbuscula and $U$. cylindrica, the lichens were surface-sterilized in $20 \%$ hydrogen peroxide $\left(\mathrm{H}_{2} \mathrm{O}_{2}\right)$ for $5 \mathrm{~min}$ followed by three washes for $5 \mathrm{~min}$ in sterile $0.85 \% \mathrm{NaCl}$ solution. The surface-sterilized material was imprinted on nutrient agar as a sterility check. To each sample, $2 \mathrm{ml}$ of sterile $\mathrm{NaCl}$ solution $(0.85 \%)$ was added and all samples were homogenized with mortar and pestle. Suspensions containing material from L. polytropa as well as suspensions obtained by extracting the ecto- and endolichenic bacterial fraction of $C$. arbuscula and $U$. cylindrica were serially diluted and plated onto nutrient-poor R2A agar and incubated at $20^{\circ} \mathrm{C}$ for 5 days. Between 100 and 150 colonies of for each lichen were randomly selected, purified and stored in broth containing 15\% glycerol at $-70^{\circ} \mathrm{C}$.

Screening for functions of cultured strains

Macromolecular hydrolytic activity. Chitinase activity ( $\beta$-1,4-glucosamine polymer degradation) was tested on chitin minimal medium by the method described by Chernin et al. (1995). Clearing zones were detected 5 days after incubation at $20^{\circ} \mathrm{C}$. $\beta$-Glucanase activity was tested by using chromogenic (azurine-dyed, cross-linked) substrates (Megazyme, Bray, Ireland). Formation of blue halos was recorded until 5 days after incubation. Protease activity (casein degradation) was determined from clearing zones on skim milk agar $(50 \mathrm{ml}$ of sterilized skim milk mixed at $55^{\circ} \mathrm{C}$ with $50 \mathrm{ml}$ of one-fifth tryptic soy agar and $4 \%$ agar) 5 days after incubation at $20^{\circ} \mathrm{C}$.

Nitrogen fixation. The ability to fix atmospheric nitrogen under in vitro conditions was tested similar to Cardinale et al. (2006), but here using a semisolid Brown's N-free medium: $5 \mathrm{~g}$ glucose, $5 \mathrm{~g}$ mannitol, $0.8 \mathrm{~g} \mathrm{~K}_{2} \mathrm{PO}_{4}, 0.2 \mathrm{~g} \mathrm{MgSO}_{4} \times 7 \mathrm{H}_{2} \mathrm{O}, 0.15 \mathrm{~g} \mathrm{CaCl}_{2}, 0.04 \mathrm{~g}$ $\mathrm{FeSO}_{4} \times 7 \mathrm{H}_{2} \mathrm{O}, 0.005 \mathrm{~g} \mathrm{Na}_{2} \mathrm{MO}_{4} \times 2 \mathrm{H}_{2} \mathrm{O}, 0.3 \mathrm{~g} \mathrm{NEEO}$ Agarose (Carl Roth, Karlsruhe, Germany), distilled water to 1 liter. Bacterial growth on the $\mathrm{N}$-free medium was compared with the growth on Brown's medium amended with an organic nitrogen source $\left(2 \mathrm{gl}^{-1}\right.$ casamino acids) after $1-2$ days at $20^{\circ} \mathrm{C}$. Isolates growing in absence of organic nitrogen as fast as on the control medium were denoted as nitrogen-fixing bacteria.

Phosphate solubilization. Antagonistic bacteria were screened for their ability to solubilize phosphate by an in vitro plate assay using NBRIP media supplemented with $1.5 \%$ agar as described by Nautiyal (1999).

Detection of indole-3-acetic acid. Indole-3-acetic acid (IAA) excretion by bacterial strains was determined by means of a modified colorimetric analysis developed by Sawar and Kremer (1995). Growth medium consisting of glucose (5.0 g), yeast extract $(25.0 \mathrm{mg})$, L-tryptophane $(0.2 \mathrm{~g})$ and distilled water (to 1.0 liter) was inoculated with cell material from the preculture $\left(0.5 \times \mathrm{TSA}, 30^{\circ} \mathrm{C}, 24 \mathrm{~h}\right)$ to an $\mathrm{OD}_{600}$ of 0.5 . After cultivation at $20^{\circ} \mathrm{C}$ and 150 r.p.m. for $72 \mathrm{~h}$ in absence of light, cell-free supernatant was mixed with Salkowski reagent $\left(50.0 \mathrm{mM} \mathrm{FeCl}_{3}\right.$, $35.0 \%(\mathrm{v} / \mathrm{v})$ perchloric acid) at the ratio of $3: 2$ and incubated for $30 \mathrm{~min}$ in absence of light. IAA concentration was measured photospectrometrically using the microplate reader Spectramax 250 (Molecular Devices, Union City, CA, USA) at $530 \mathrm{~nm}$ and quantified using standard curve.

Antagonistic activity. Bacterial isolates were screened for their activity toward fungi and bacteria Verticillium dahliae KLEB, Rhizoctonia solani, Botrytis cinerea, Phytopthora infestans, Candida albicans as well as against Erwinia carotovora and Staphylococcus aureus by a dual-culture in vitro assay on the current media: Waksman agar containing $5 \mathrm{~g}$ of proteose-peptone (Merck, Darmstadt, Germany), $10 \mathrm{~g}$ of glucose (Merck), $3 \mathrm{~g}$ of meat extract (Chemex, Munich, Germany), $5 \mathrm{~g}$ of $\mathrm{NaCl}$ (Merck), $20 \mathrm{~g}$ of agar (Difco, Detroit, MI, USA) and distilled water (to 1 liter) ( $\mathrm{pH}$ 6.8); potato-extract glucose agar (PGA) containing $26.5 \mathrm{~g}$ of potato extract glucose (Roth), $20 \mathrm{~g}$ of agar (Difco) in distilled water (1 liter); pea agar with extract of pea (150 g) boiled for $20 \mathrm{~min}, 20 \mathrm{~g}$ of agar (Difco) and distilled water (1 liter) and LB agar containing $25 \mathrm{~g}$ of LB broth (Roth), $20 \mathrm{~g}$ of agar and distilled water 
(1 liter). Zones of inhibition were measured after 3 and 7 days of incubation at $20^{\circ} \mathrm{C}$ according to the method described by Berg et al. (2002).

\section{Identification of cultured strains and phylogenetic analysis}

Bacterial genomic DNAs were extracted by the lysozyme-proteinase K-sodium dodecyl sulfate method (modified by increasing the reagent concentration to $2.4 \mathrm{mg} \mathrm{ml}^{-1}$ of lysozyme, $0.5 \mathrm{mg} \mathrm{ml}^{-1}$ of proteinase $\mathrm{K}$ and of $0.8 \%$ of sodium dodecyl sulfate). Amplified ribosomal DNA restriction analysis (ARDRA) was performed with the endonuclease HhaI. Representatives of individual cultured strains as assessed by ARDRA were identified by PCR amplification of the 16S rDNA fragment between positions 14 and 907 (according to E. coli $16 \mathrm{~S}$ rDNA sequence numbering) and sequencing using the primers Eub1 (5'-AGATTTGATCMTGGCT CAG-3') and 907r (5'-CCGTCAATTCMTTTGAGTTT$\left.3^{\prime}\right)$. PCR products were purified with the GENECLEAN Turbo kit (BIO101 Systems; Qbiogene). Complementary strands of DNA were sequenced using the BigDye Terminator Ready Reaction kit (Applied Biosystems, Norwalk, CT, USA) and sequencing reactions were separated on an ABI 310 automated sequencer (Applied Biosystems). Relationships were assessed by BLAST searches. Sequences were submitted to GenBank (accession nos. FN298879-FN298916).

The partial sequences of the 16S rRNA genes from our isolates, the best BLAST-matching sequences and some reference sequences were aligned by ClustalX (Thompson et al., 1994). A $550 \mathrm{nt}$ multialignment was obtained and the PHYLIP package (Felsenstein, 2004; http://evolution.genetics.washington.edu/phylip.html) was used for producing the bootstrap replicates (program SeqBoot), for inferring the maximum likelihood tree (program DNAml), the neighbor-joining (programs dnadist and neighbor) and for calculating the consensus trees (program consense). The phylogenetic tree was constructed with the Neighbor software of the PHYLIP package. TreeView (Page, 1996; http:// taxonomy.zoology.gla.ac.uk/rod/treeview.html) was used for the visualization of the trees.

\section{Results}

Fluorescence in situ hybridization

Functionally distinct layers of lichens are differentially colonized by bacteria. We investigated the location and abundance of bacteria directly in the stratified lichen thalli using CLSM. Reindeer lichens of the genus Cladonia form mycelial cylinders with the photosynthetic algal partners exposed on their external surface. In contrast, bacteria form morphologically diverse, biofilm-like communities on the internal surface of these cylinders (Figure 2a), and much fewer bacteria colonize the external surface. Semi-automated quantification of CLSM images uncovers an abundance that ranged from $10^{4}$ to $10^{6}$ bacteria per cubic millimeter of lichen volume (C. arbuscula: $1.2 \times 10^{6} \pm 0.2$, L. polytropa: $7.4 \times 10^{5} \pm 1.2$ and $U$. cylindrica: $9.0 \times 10^{5} \pm 2.0$ ). We found similar abundances in primordial tips of the thalli as well as in their senescing bases. FISH with group-specific probes reveal a prevalence of Alphaproteobacteria (45-75\%) in these communities, whereas other groups of bacteria were present at lower abundances. Bacteria colonized not only the surface of the extracellular polysaccharides, but also immersed into the intercellular gelatinous matrix (Figure 2b). In $U$. cylindrica bacteria were highly abundant in shallow pits on the lower surface, well separated from the algal partners (Figure 2c,d), and in the crustose L. polytropa, these form dense clusters between hyphal strands and algae (Figure 2e, f).

\section{Microbial fingerprints of lichen-associated bacterial communities}

PCR-SSCP fingerprints of bacterial communities from the three lichen species were compared for both universal bacterial and group-specific fingerprints (Alphaproteobacteria, Pseudomonas, Burkholderia). Specific primers for Alphaproteobacteria, as well as the genus-specific primers for either Burkholderia or Pseudomonas revealed complex SSCP patterns: Burkholderia and Pseudomonas communities are highly diverse in all lichens, whereas more similarity throughout was found for Alphaproteobacteria. The qualitative analysis of microbial fingerprints showed specific patterns for each of the investigated lichens. However, specificity was different and depended on the primer system used. The application of universal primer for bacteria resulted in statistically significant differences at both sampling times (C. arbuscula- $U$. cylindrica $P \leqslant 0.0029,0.0021 ; C$. arbuscula-L. polytropa $P \leqslant 0.0115$, 0.0360; U. cylindrica-L. polytropa $P \leqslant 0.0108,0.0118$ ). This is shown in Figure 3 , which represents the cluster analysis for the first sampling time. These species-specific patterns were confirmed by using primers targeting Alphaproteobacteria (C. arbuscula-U. cylindrica $P \leqslant 0.0046$, $0.0021 ;$ C. arbuscula-L. polytropa $P \leqslant 0.0286$, $0.0118 ; \quad U$. cylindrica-L. polytropa $P \leqslant 0.0356$, 0.5957 ) as well as Burkholderia (C. arbuscula-U. cylindrica $P \leqslant 0.0043,0.0021$; C. arbuscula-L. polytropa $P \leqslant 0.0116,0.0372$; U. cylindrica-L. polytropa $P \leqslant 0.0108,0.2506$ ). In contrast, the applications of Pseudomonas-specific primers showed no distinct patterns. Two fractions of the lichen thallus (endoand ectolichenic) were investigated (with exception of Lecanora). The endolichenic microbial community, which was obtained after surface sterilization of lichens, was generally more specific than those which contain also bacterial communities from the lichen surface. Furthermore, the bacterial 

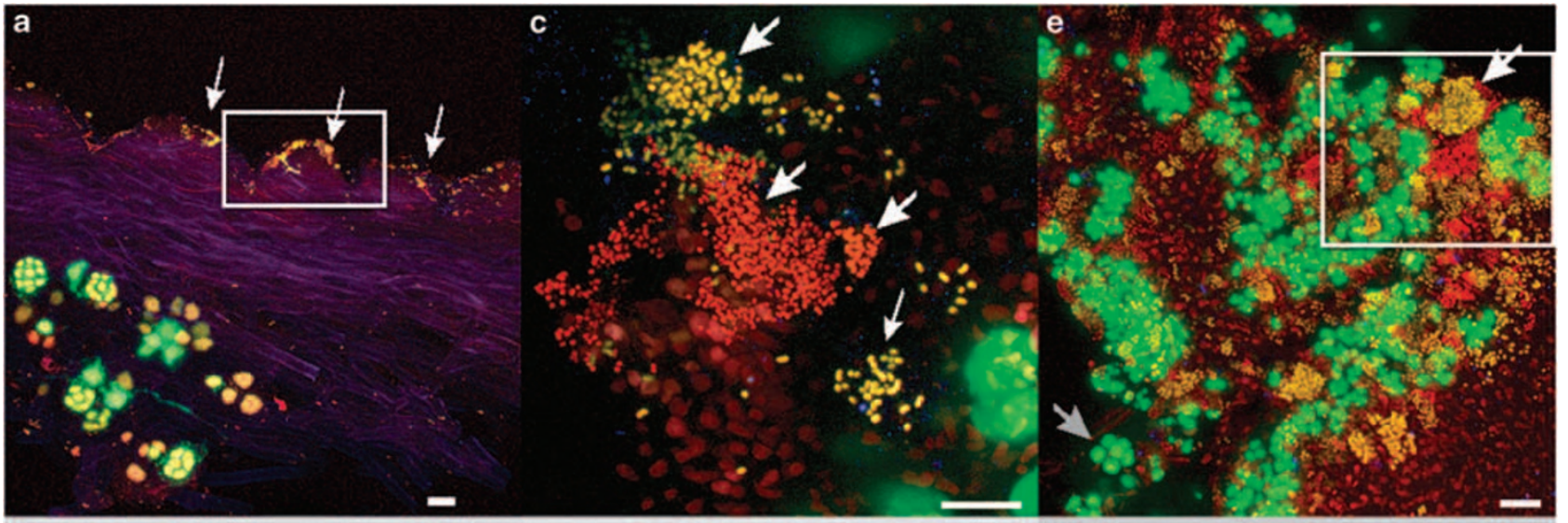

b

d f
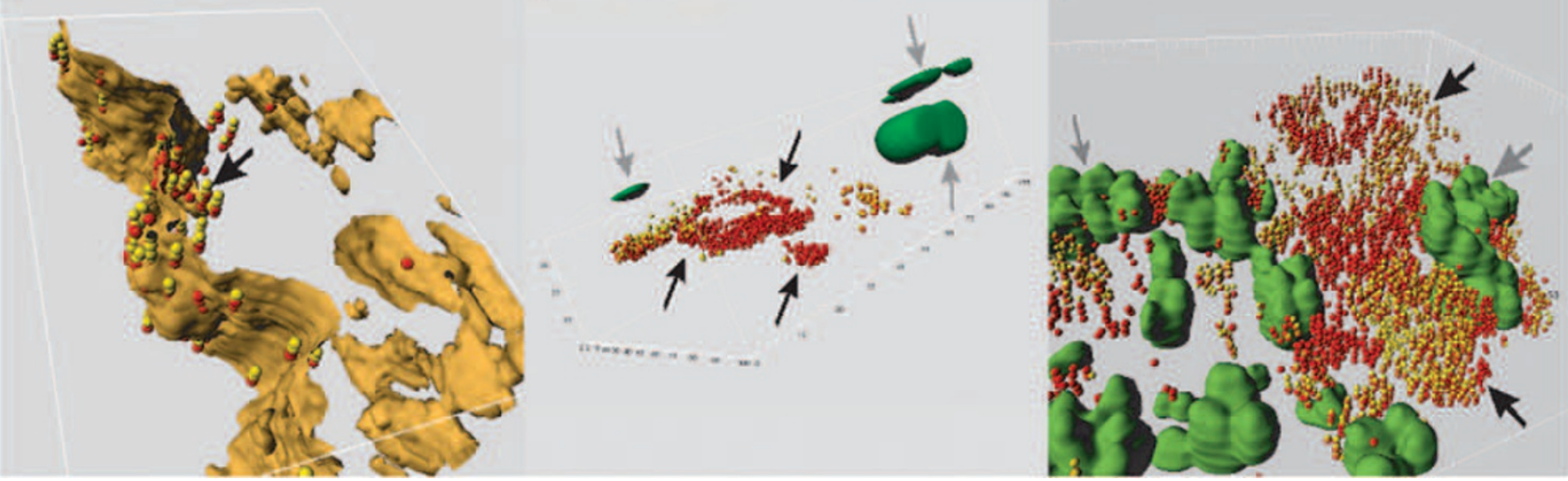

Figure 2 Localization of bacteria in lichens by confocal laser-scanning microscopy (CLSM) and fluorescence in situ hybridization (FISH). Yellow: Alphaproteobacteria, red: other bacteria, green: eukaryotic algal cells, blue/pink: fungal hyphae. (a) Colonization of inner surfaces in C. arbuscula (arrow). (b) 3D reconstruction from the framed region in (a) shows bacteria below the surface of extracellular polysaccharides (arrow). (c) Lower surface of $U$. cylindrica with dense clusters of bacteria (arrow). (d) 3D reconstruction of (c) reveals bacterial community (black arrow) growing well separated from the algal cells (gray arrow). (e) Basal parts of L. polytropa with mixture of algal cells (gray arrow) and bacterial colonies (white arrow). (f) 3D reconstructions of the framed region in (e) with bacteria growing (black arrow) abundantly among the algal colonies (gray arrow). Scale bar $=15 \mu \mathrm{m}$.

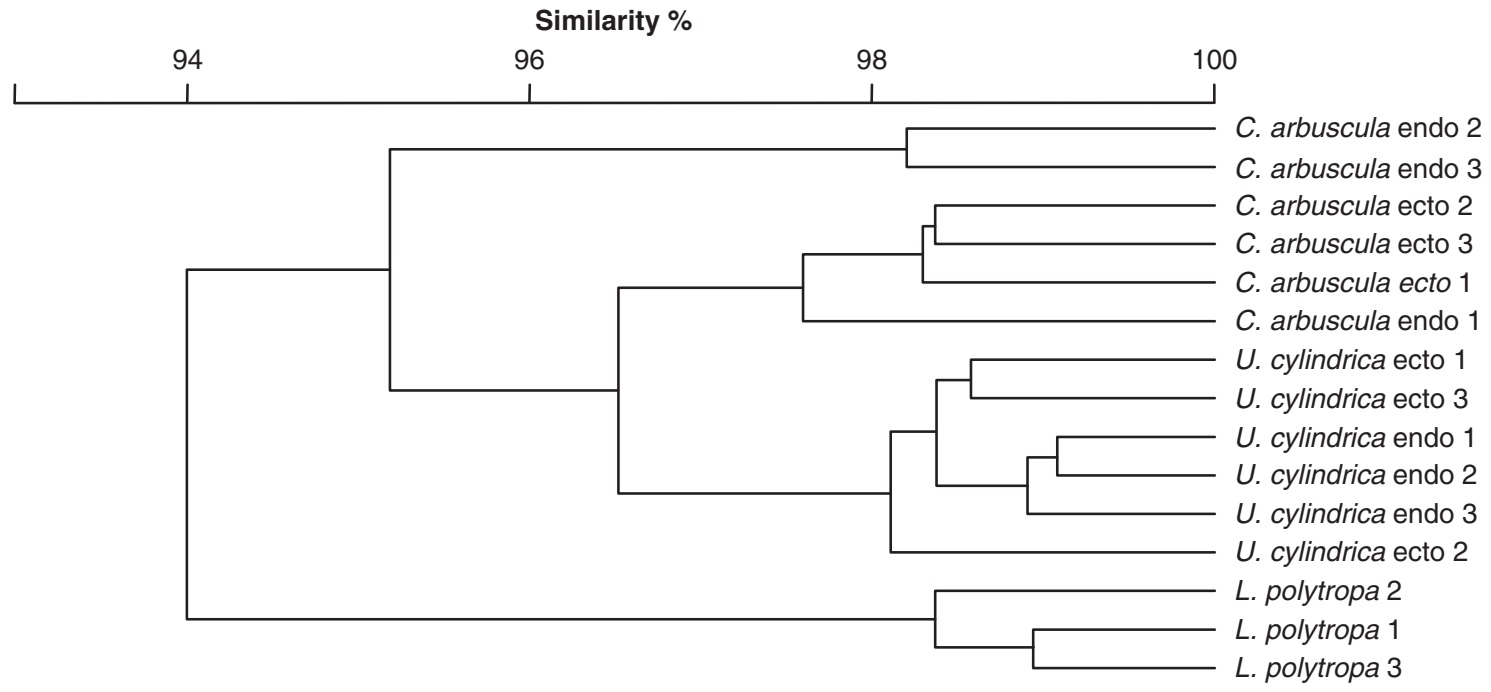

Figure 3 Similarities of single-strand conformation polymorphism (SSCP) profiles from total bacterial communities in lichens. Ectoand endolichenic bacterial communities designated endo and ecto, respectively, were analyzed from $C$. arbuscula and $U$. cylindrica.

community of the soil-inhabiting reindeer lichen $C$. arbuscula was more distinct from the more similar communities of the rock-inhabiting $U$. cylindrica and L. polytropa. In addition, SSCPs using nifHspecific primers indicate the presence of nitrogenase genes in the total bacterial fraction. Our sequence 
Table 2 Identification and taxonomic classification of DNA bands separated by SSCP from different lichens

\begin{tabular}{|c|c|c|c|c|}
\hline No. & Origin: lichen species & Primer in SSCP & $\begin{array}{l}\text { Closest NCBI database match } \\
\text { and accession number }\end{array}$ & $\underset{(\%)}{\text { Similarity }}$ \\
\hline N1 & C. arbuscula & NifH gene & $\begin{array}{l}\text { Beijerinckia derxii subsp. derxii } \\
\text { AJ563940 }\end{array}$ & 86 \\
\hline N3 & C. arbuscula & NifH gene & $\begin{array}{l}\text { Paenibacillus durus } \\
\text { AJ515294 }\end{array}$ & 87 \\
\hline A3 & C. arbuscula & Alphaproteobacteria & $\begin{array}{l}\text { Acidisphaera rubrifaciens } \\
\text { D86512 }\end{array}$ & 95 \\
\hline N4 & U. cylindrica & NifH gene & $\begin{array}{l}\text { Stenotrophomonas maltophilia } \\
\text { DQ } 431165\end{array}$ & 94 \\
\hline N7 & U. cylindrica & NifH gene & $\begin{array}{l}\text { Methylocystis echinoides } \\
\text { AM110703 }\end{array}$ & 88 \\
\hline B6 & U. cylindrica & Alphaproteobacteria & $\begin{array}{l}\text { Uncultured Gluconacetobacter sp. } \\
\text { DQ499979 }\end{array}$ & 95 \\
\hline B8 & U. cylindrica & Alphaproteobacteria & $\begin{array}{l}\text { Acidisoma tundrae } \\
\text { AM947652 }\end{array}$ & 96 \\
\hline B9 & U. cylindrica & Alphaproteobacteria & $\begin{array}{l}\text { Uncultured Sphingomonas sp. } \\
\text { AM944544 }\end{array}$ & 100 \\
\hline B11 & U. cylindrica & Alphaproteobacteria & $\begin{array}{l}\text { Acidisoma sibirica } \\
\text { AM947654 }\end{array}$ & 97 \\
\hline
\end{tabular}

data show that nifH genes present in all lichens are from Alphaproteobacteria, Gammaproteobacteria and Firmicutes (Table 2). Sequencing of excised SSCP bands showed that most Alphaproteobacteria belong to strains of Acetobacteraceae (for example, Gluconacetobacter and Acidisoma), but others were also present (Sphingomonas) (Table 2).

Bacterial abundances in lichens

The counts of colony-forming units (CFU) in the two sampling were in agreement with high abundances of bacteria found by microscopy in the soil-inhabiting $C$. arbuscula (3.4-4.7 $\times 10^{7} \mathrm{CFU}$ per gram) and in the rock-inhabiting $U$. cylindrica $\left(1.3-2.1 \times 10^{7} \mathrm{CFU}\right.$ per gram). Lower counts were found in L. polytropa (1.6-4.1 $\times 10^{4} \mathrm{CFU}$ per gram).

\section{Identification of cultured strains}

To identify the bacterial strains, partial 16S rRNA gene sequences were used to reconstruct a phylogenetic tree (Figure 4). In contrast to the microscopic observations that showed a dominance of Alphaproteobacteria, a broad phylogenetic spectrum of the culturable fraction was found. Altogether, 12 bacterial genera were identified: Acinetobacter, Bacillus, Burkholderia, Frondicola, Leifsonia, Luteibacter, Methylobacterium, Microbacterium, Micrococcus, Paenibacillus, Pseudomonas and Sphingomonas. Data obtained from cultured strains assign the ubiquity strains to Acinetobacter, Bacillus, Burkholderia and Paenibacillus, whereas other bacteria were less abundant (for example, strains assigned to Frondicola, Luteibacter, Methylobacterium as well as unnamed and potentially new lineages) or retrieved from one sampling time only (for example, Pseudomonas and Leifsonia). The group including Actinobacteria-related isolates seem to be the most complex and less stable but it was not possible in this work to obtain a consistent phylogenetic inference, due to the fact that most of our actinobacterial isolates showed the same similarity with different known species and the best BLAST-matching sequences refer to unidentified environmental strains (data not shown).

About one-tenth of the culturable colonies retrieved from the lichen species $(N=261)$ were able to grow both on semisolid $\mathrm{N}$-free and on nutrientrich medium. Many of our culturable strains displayed lytic activities (proteolytic: $50 \%$, chitinolytic: $14 \%$, glucanolytic: $29 \%$ ), whereas $23 \%$ of the strains showed phosphate-solubilizing activity. In addition, $21 \%$ of our cultured strains produced the growth-promoting hormone IAA. The strains were also tested regarding their in vitro antagonism toward other microorganisms. In general, a low antagonistic activity was found for the lichenassociated bacteria. The proportion of antagonistic isolates was $4.2 \%$ against B. cinerea and $2.3 \%$ against $V$. dahliae (both plant pathogenic ascomycetes), $1.5 \%$ against $R$. solani (plant pathogenic basidiomycetes), $3.4 \%$ against $P$. infestans (plant pathogenic oomycetes), $2 \%$ against $S$. aureus (Grampositive, human pathogenic bacterium) and 1.5\% against E. carotovora (Gram-negative, plant pathogenic bacterium).

\section{Discussion}

Our data present lichens as more complex symbiotic systems than thought previously. According to the traditional view of functions, lichen photobionts provide carbohydrates to their fungal partners, which develop the structural framework rendering 
Figure 4 Maximum likelihood tree based on 16S rRNA gene multialignment ( $550 \mathrm{nt}$ ) showing the phylogenetic relationships between sequences of lichen-associated bacteria, the correspondent best BLAST-matching sequences and some reference sequences. Sequences from lichen-associated bacteria are highlighted in bold; lichen host and location (ecto- or endophytic) are indicated after the isolate name. The sequences from lichen-associated bacteria including an accession number were obtained from Cardinale et al. (2006). The numbers at node positions indicate the bootstrap values (calculated by maximum likelihood/neighbor-joining methods) out of 1000 resampling of the data. Roots of genus clades are labeled at the correspondent nodes.

optimal performance of the entire symbiotic system. In addition to the two keystone partners, lichens can benefit from complementary functions of associated bacterial communities as microsymbionts. For example, diazotrophic bacteria potentially complement the nitrogen budget in lichens with eukaryotic algae. Diazotrophic bacteria in lichens are not restricted to a particular group. We found diverse nifH sequences representative for different bacterial branches: Gammaproteobacteria, and Firmicutes but with a dominance of Alphaproteobacteria. All identified nifH genes belong to species that are well known for symbiotic nitrogen fixation and their beneficial and endophytic interaction with 
plants resulting in plant growth promotion (Ryan et al., 2008). For tropical lichens, dot-blot detection of nifH genes in strains from $\mathrm{N}$-free enrichment cultures as well as positive acetylene reduction (Liba et al., 2006) suggests widespread potential and importance of bacterial nitrogen fixation in greenalgal lichens. The proportion of bacteria with lytic activities was higher than found with plant-associated bacteria (Berg et al., 2002) whereas antifungal activity was lower (less than $5 \%$ of the strains). We hypothesize that lytic bacteria are involved in nutrient cycling in the lichen thalli, although metabolite fluxes in the natural lichens are not yet quantified. The occurrence of a substantial proportion of auxin-producing bacteria in the lichen symbiosis supports the intimate interaction between the bacterial community and the lichen fungus because the phytohormone auxin has not only a function in plant-microbe interaction but also on fungal growth (Grube and Berg, 2009).

Extracellular polysaccharides and cell wall components of lichen fungi are lasting nutrient sources, which are also exploitable when the fungal and algal partners are metabolically inactive. Differences in the composition and abundance of bacteria in lichens are apparently regulated by still unknown mechanisms that also help to protect against invasions by pathogenic bacteria. Diverse secondary metabolites with antibacterial activities known from lichens potentially contribute to this function (Boustie and Grube, 2005). The dibenzofurane usnic acid is active against Gram-positive bacteria (Ingólfsdóttir, 2002) and strongly influences bacterial biofilm formation (Francolini et al., 2004). This agrees with the low abundance of bacteria on usnic acid-containing external surfaces in growing upper parts of $C$. arbuscula, whereas the degrading basal parts were richly colonized also on the external side (Cardinale and Steinova, personal communication).

The growth of most lichens is indeterminate and not limited by age-specific death rates under undisturbed environmental conditions (for example, absence of grazing animals or air pollution). Parts of a lichen thallus can then locally senesce, whereas biomass increases in actively growing parts. Recycling and translocation of components are of key importance for robustness and longevity of lichens in nutrient-poor habitats. Such parsimonious management of resources will be of particular importance for surface-detached lichens with little contact to the underlying substrate. Umbilicaria species connect to the substrate only with a narrow central holdfast, whereas shrub-like thalli of reindeer lichens have senescing basal parts and completely lack a soil-exploiting mycelium. Experimental studies demonstrated the translocation of fixed nitrogen compounds from the base to the tip in mat-forming reindeer lichens (Ellis et al., 2005). We argue that lytic, N-fixing and phosphate-solubilizing bacteria may significantly enhance the mobilization of nutrients. The mobilized nutrients may originate either from the lichen itself or from the supporting substrate. Recent experiments showed increased solubilization of mineral substrate in co-cultures of an isolated lichen fungus with N-fixing Bradyrhizobium elkanii (Seneviratne and Indrasena, 2006). Efficient rock weathering by cooperating bacteria and fungi could explain the abundance of bacterial communities in basal parts of $L$. polytropa.

The analogy proposed by Farrar (1985), that lichens be viewed as self-contained ecosystems, is here extended to include associated, nonphotosynthetic bacterial communities as multifunctional partners in the symbiotic assembly. This adds to recent amendments in other symbiotic systems, for example, sponges and corals, but also invertebrates, which now turn out to be complex multisymbioses (Hunter, 2006). The abundance of bacteria and their potential function in these long-living holobionts will initiate more detailed studies on further aspects of these unique associations, including their evolution and biogeographic patterns, and also the function of particular bacteria for the entire lichen holobiont. Products of some lichen-associated bacteria were shown to be potent antibiotics at very low concentrations (Davies et al., 2005), which suggests that also less abundant strains could have significant functional role in the lichen microecosystem. The evolutionary diversification of lichens is characterized by adaptation to an extremely wide range of environments in which bacterial communities are involved. We suppose that bacterial strains that maintain the lichen symbiosis in different ecological situations might in a long run assist in the ecological adaptation of lichens. Thus, lichen evolution could to some extent be pushed by bacterial powers. On the other hand, lichens as unique habitats could promote bacterial diversification, especially in dense biofilm-like structures (Hansen et al., 2007). Lichens can also tolerate extreme abiotic stressors (including extreme climates, salt, radionuclides and so on) and accumulate toxic compounds (heavy metals and so on). We are therefore convinced that they may turn out as hot bed of bacterial diversity and as sources of biotechnologically interesting strains, compounds and enzymes (Davies et al., 2005; Gonzáles et al., 2005).

\section{Acknowledgements}

We thank David Hawksworth, Ilse Kranner and Martin Hagemann for comments. This research was funded by a grant from the Austrian Science Foundation (FWF) to MG and GB.

\section{References}

Amann RI, Binder BJ, Olson RJ, Chisholm SW, Devereux R, Stahl DA. (1990). Combination of $16 \mathrm{~S}$ rRNAtargeted oligonucleotide probes with flow cytometry 
for analyzing mixed microbial populations. Appl Environ Microbiol 56: 1919-1925.

Berg G, Krechel A, Ditz M, Faupel A, Ulrich A, Hallmann J. (2005). Comparison of endophytic and ectophytic potato-associated bacterial communities and their antagonistic activity against plant pathogenic fungi. FEMS Microbiol Ecol 51: 215-229.

Berg G, Roskot N, Steidle A, Eberl L, Zock A, Smalla K. (2002). Plant-dependent genotypic and phenotypic diversity of antagonistic rhizobacteria isolated from different Verticillium host plants. Appl Environ Microbiol 68: 3328-3338.

Blackwood CB, Oaks A, Byuer JS. (2005). Phylum- and class-specific PCR primers for general microbial community analysis. Appl Environm Microbiol 71: 6193-6198.

Boustie J, Grube M. (2005). Lichens-a promising source of bioactive secondary metabolites. Pl Gen Res 3: 273-287.

Cardinale M, Puglia AM, Grube M. (2006). Molecular analysis of lichen-associated bacterial communities. FEMS Microbiol Ecol 57: 484-495.

Cardinale M, de Castro Junior J, Müller H, Berg G, Grube M. (2008). In situ analysis of the bacterial community associated with the reindeer lichen Cladonia arbuscula reveals predominance of Alphaproteobacteria. FEMS Microb Ecol 66: 63-71.

Chernin L, Ismailov Z, Haran S, Chet I. (1995). Chitinolytic Enterobacter agglomerans antagonistic to fungal plant pathogens. Appl Environ Microbiol 61: 1720-1726.

Daims H, Brühl A, Amann R, Schleifer KH, Wagner M. (1999). The domain-specific probe EUB338 is insufficient for the detection of all bacteria: development and evaluation of a more comprehensive probe set. Syst Appl Microbiol 22: 434-444.

Davies J, Wang H, Taylor T, Warabi K, Huang X-H, Andersen RJ. (2005). Uncialamycin, a new enediyne antibiotic. Org Lett 7: 5233-5236.

Denton GH, Karlén W. (1973). Lichenometry: its application to Holocene moraine studies in Southern Alaska and Swedish Lapland. Arctic Alpine Res 5: 347-372.

Ellis CJ, Crittenden PD, Scrimgeour CM, Ashcroft CJ. (2005). Translocation of ${ }^{15} \mathrm{~N}$ indicates nitrogen recycling in the mat-forming lichen Cladonia portentosa. New Phytol 168: 423-434.

Erhart RD, Bradford RJ, Seviour R, Amann RI, Blackall LL. (1997). Development and use of fluorescent in situ hybridization probes for the detection and identification of Microthrix parvicella in activated sludge. Syst Appl Microbiol 20: 310-318.

Farrar JF. (1985). The lichen as an ecosystem: observation and experiment. In: Brown DH, Hawksworth DL, Bailey RH (eds). Lichenology: Progress and Problems. Academic Press: London, pp 385-406.

Felsenstein J. (2004). PHYLIP (Phylogeny Inference Package) version 3.6. Distributed by the author Department of Genome Sciences, University of Washington, Seattle.

Francolini I, Norris P, Piozzi A, Donelli G, Stoodley P. (2004). Usnic acid, a natural antimicrobial agent able to inhibit bacterial biofilm formation on polymer surfaces. Antimicrob Agents Chemother 48: 4360-4365.

Gonzáles I, Ayuso-Sacido A, Anderson A, Genilloud O. (2005). Actinomycetes isolated from lichens: evaluation of their diversity and detection of biosynthetic gene sequences. FEMS Microbiol Ecol 54: 401-415.

Grube M, Hawksworth DL. (2007). Trouble with lichen: the re-evaluation and re-interpretation of thallus form and fruit body types in the molecular era. Mycol Res 111: 1116-1132.

Grube M, Berg G. (2009). Bacterial associations with fungi, focusing on the lichen symbiosis. Fungal Biol Rev (in press).

Hansen SK, Rainey RB, Haagensen JAJ, Molin S. (2007). Evolution of species interactions in a biofilm community. Nature 445: 533-536.

Hawksworth DL. (1988). The variety of fungal-algal symbioses, their evolutionary significance, and the nature of lichens. Bot J Linn Soc 96: 3-20.

Henkel PA, Plotnikova TT. (1973). Nitrogen-fixing bacteria in lichens. Izv Akad Nauk Ser Biol 1973: 807-813.

Henkel PA, Yuzhakova LA. (1936). Nitrogen-fixing bacteria in lichens. Izv Biol Inst Permsk Gos Univ 10: 9-10.

Hunter P. (2006). Entente cordiale: multiple symbiosis illustrates the intricate interconnectivity of nature. EMBO Rep 7: 861-864.

Ingólfsdóttir K. (2002). Usnic acid. Phytochem 61: 729-736.

Iskina RY. (1938). On nitrogen fixing bacteria in lichens. Isv Biol Inst Permsk 11: 133-139.

Kneip C, Lockhart P, Voss C, Maier UG. (2007). Nitrogen fixation in eukaryotes-new models for symbiosis. BMC Evol Biol 7: 55.

Kropf S, Heuer H, Grüning, Smalla K. (2004). Significance test for comparing complex microbial community fingerprints using pairwise similarity measures. J Microbiol Methods 57: 187-195.

Lawrey JD, Diederich P. (2003). Lichenicolous fungi: interactions, evolution, and biodiversity. Bryologist 106: 81-120.

Lenova LI, Blum O. (1983). To the question on the third component of lichens. Bot J 68: 21-28.

Liba CM, Ferrara FIS, Mangio GP, Fantinatti-Garboggini F, Albuquerque RC, Pavan C et al. (2006). Nitrogen-fixing chemo-organotrophic bacteria isolated from cyanobacteria-deprived lichens and their ability to solubilize phosphate and to release amino acids and phytohormones. J Appl Microbiol 101: 1076-1086.

Loy A, Maixner F, Wagner M, Horn M. (2007). probeBasean online resource for rRNA-targeted oligonucleotide probes: new features 2007. Nucleic Acids Res 35: D800-D804.

Lutzoni F, Pagel M, Reeb V. (2001). Major fungal lineages are derived from lichen symbiotic ancestors. Nature 411: 937-940.

Manz W, Amann R, Ludwig W, Wagner M, Schleifer KH. (1992). Phylogenetic oligodeoxynucleotide probes for the major subclasses of proteobacteria: problems and solutions. Syst Appl Microbiol 15: 593-600.

Meier H, Amann R, Ludwig W, Schleifer KH. (1999). Specific oligonucleotide probes for in situ detection of a major group of Gram-positive bacteria with low DNA G1C content. Syst Appl Microbiol 22: 186-196.

Nautiyal CS. (1999). An efficient microbiological growth medium for screening phosphate solubilizing microorganisms. FEMS Microbiol Ecol 170: 265-270.

Opelt K, Berg G. (2004). Diversity and antagonistic potential of bacteria associated with bryophytes from 
nutrient-poor habitats of the Baltic Sea Coast. Appl Environ Microbiol 70: 6569-6579.

Page RD. (1996). TreeView: an application to display phylogenetic trees on personal computers. Comput Appl Biosci 12: 357-358.

Panosyan AK, Nikogosyan VG. (1966). The presence of Azotobacter in lichens. Akad Nauk Armian SSR Biol Zhurn Armen 19: 3-11.

Ryan RP, Germaine K, Franks A, Ryan DJ, Dowling DN. (2008). Bacterial endophytes: recent developments and applications. FEMS Microbiol Lett 278: 1-9.

Sawar M, Kremer RJ. (1995). Determination of bacterially derived auxins using a microplate method. Lett Appl Microbiol 20: 282-285.

Schwieger F, Tebbe CC. (1998). A new approach to utilize PCR-single-strand-conformation polymorphism for 16S rRNA gene-based microbial community analysis. Appl Environ Microbiol 64: 4870-4876.

Scott GD. (1956). Further investigations of some lichens for fixation of nitrogen. New Phytol 55: 111-116.
Seneviratne G, Indrasena IK. (2006). Nitrogen fixation in lichens is important for improved rock weathering. J Biosci 31: 639-643.

Thompson JD, Higgins DG, Gibson TJ. (1994). CLUSTAL $\mathrm{W}$ : improving the sensitivity of progressive multiple sequence alignment through sequence weighting, position-specific gap penalties and weight matrix choice. Nucleic Acids Res 22: 4673-4680.

Wallner G, Amann R, Beisker W. (1993). Optimizing fluorescent in situ hybridization with rRNA-targeted oligonucleotide probes for flow cytometric identification of microorganisms. Cytometry 14: 136-143.

Yeager C, Kornosky JL, Housman DC, Grote EE, Belnap J, Kuske CR. (2004). Diazotrophic community structure and function in two successional stages of biological soil crusts from the Colorado plateau and Chihuahuan desert. Appl Environ Microbiol 70: 973-983.

Yuan X, Xiao S, Taylor TN. (2005). Lichen-like symbiosis 600 million years ago. Science 308: 1017-1020. 